\title{
Aarskog syndrome
}

\author{
Mary E M Porteous, David R Goudie
}

Aarskog syndrome (facio-digital-genital syndrome) was first described in 1970 by Dagfin Aarskog ${ }^{1}$ who presented seven males from one family with a growth disorder and associated anomalies. A year later Scott ${ }^{2}$ reported three brothers with similar features and since then there have been over 100 cases published. ${ }^{3-20} \mathrm{We}$ are aware of 12 subjects with Aarskog syndrome living in the west of Scotland (population 1.6 million). However, owing to the benign nature of the condition, it is underdiagnosed and the true incidence must be higher than this.

\section{Inheritance}

Aarskog syndrome has been assigned to the $\mathrm{X}$ chromosome on the basis of pedigree analysis but this interpretation remains open to doubt. The importance of shawl scrotum as a clinical feature produces a diagnostic bias in favour of males. The facial features are often as obvious in female carriers as in male carriers, and in two large pedigrees male to male transmission has been found. 1120

In 1984, Bawle $e t a^{3}$ described a mother and son with Aarskog syndrome and an X;autosomal translocation (Xq13;8p21.2). In the absence of linkage data to clarify the issue, the disorder is as likely to be a partially sex limited autosomal dominant localised by the autosomal element of the translocation.

\section{Clinical features}

The table summarises the main clinical features found

Duncan Guthrie Institute of Medical Genetics, Yorkhill Hospitals, Glasgow G3 8SJ.

M E M Porteous, D R Goudie

Correspondence to Dr Porteous, Regional Genetics Advisory Service, 19 Claremont Place, Newcastle upon Tyne NE2 4AA.
Clinical features in Aarskog syndrome.

\begin{tabular}{lrc}
\hline Clinical features & $\begin{array}{c}\text { Glasgow } \\
\text { series }\end{array}$ & $\begin{array}{c}\text { Published } \\
\text { cases }\end{array}$ \\
\hline Hypertelorism & $16 / 17$ & $73 / 83$ \\
Ptosis & $8 / 17$ & $33 / 64$ \\
Downward slanting palpebral & $10 / 17$ & $33 / 64$ \\
fissures & $12 / 17$ & $30 / 45$ \\
Short nose & $12 / 17$ & $76 / 87$ \\
Wide philtrum & $12 / 17$ & $72 / 87$ \\
Maxillary hypoplasia & $14 / 17$ & $28 / 36$ \\
Anteverted nares & $9 / 17$ & $76 / 86$ \\
Abnormal auricles & $17 / 17$ & $33 / 58$ \\
Broad nasal bridge & $8 / 17$ & $72 / 82$ \\
Crease below lower lip & $8 / 17$ & $44 / 51$ \\
Widow's peak & $14 / 17$ & $49 / 60$ \\
Short/broad hands & $13 / 17$ & $50 / 60$ \\
Brachydactyly & $9 / 17$ & $36 / 56$ \\
Syndactyly & $15 / 17$ & $42 / 65$ \\
Clinodactyly & $15 / 17$ & $22 / 28$ \\
Short Sth finger & $10 / 17$ & $36 / 47$ \\
Joint laxity & $13 / 17$ & $25 / 38$ \\
Single palmar crease & $12 / 17$ & $21 / 28$ \\
Broad, short, bulbous toes & $15 / 17$ & $71 / 81$ \\
Short stature (3rd centile) & $9 / 17$ & $65 / 79$ \\
Shawl scrotum & $6 / 17$ & $54 / 77$ \\
Cryptorchidism & $11 / 17$ & $47 / 77$ \\
Inguinal herniae & $10 / 17$ & $6 / 7$ \\
Prominent umbilicus & $3 / 17$ & $31 / 57$ \\
Pectus excavatum & & \\
\hline & & \\
\hline & & \\
\hline
\end{tabular}

in Aarskog syndrome and compares the 17 males in the Glasgow series with those published previously.

Female carriers of the Aarskog gene often exhibit some of the features of the syndrome. They are usually short; all 13 women in our series were below the 10th centile for height, and many exhibit hand or facial anomalies making clinical diagnosis of carrier status possible.

\section{FACIES}

Boys with Aarskog syndrome are strikingly similar in facial appearance. Fig 1 shows two unrelated boys with Aarskog syndrome and fig 2 shows three brothers with the syndrome. Carrier females may exhibit many of the facial features (fig 3).

The cardinal features are hypertelorism, a widow's 


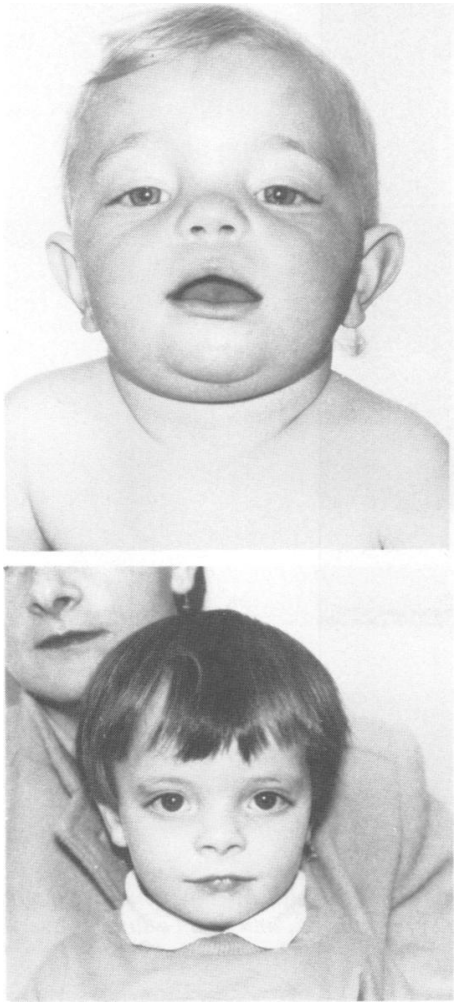

Figure 1 Two unrelated boys with Aarskog syndrome.

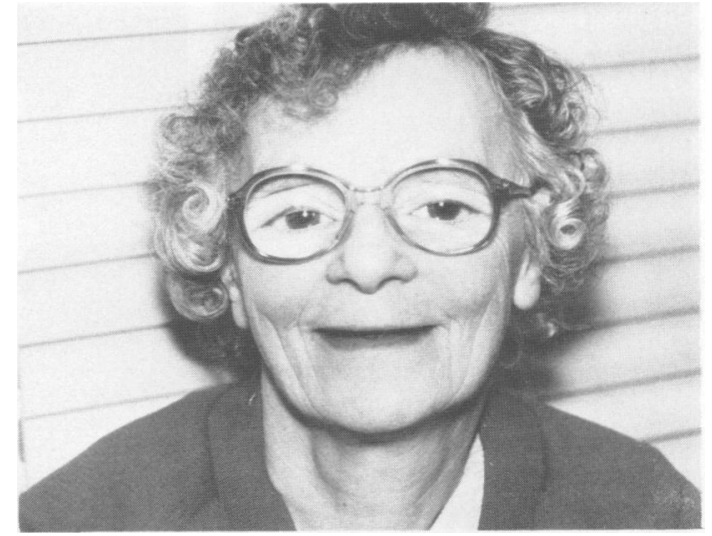

Figure 3 Female obligate gene carrier.

peak, ptosis, downward slanting palpebral fissures, small, short nose with anteverted nares, a broad nasal bridge, maxillary hypoplasia, abnormal auricles, a wide philtrum, and a crease below the lower lip. Fig 4 shows the evolution of the facial phenotype through time.

\section{SKELETAL}

Short stature in Aarskog syndrome is disproportionate, with an increased upper to lower segment ratio. The hands are short and broad with brachydactyly, syndactyly, clinodactyly, particularly short fifth fingers with single creases, single palmar creases, and striking joint laxity particularly evident in the phalanges (fig 5).

Other skeletal abnormalities which have been documented are odontoid hypoplasia with cervical

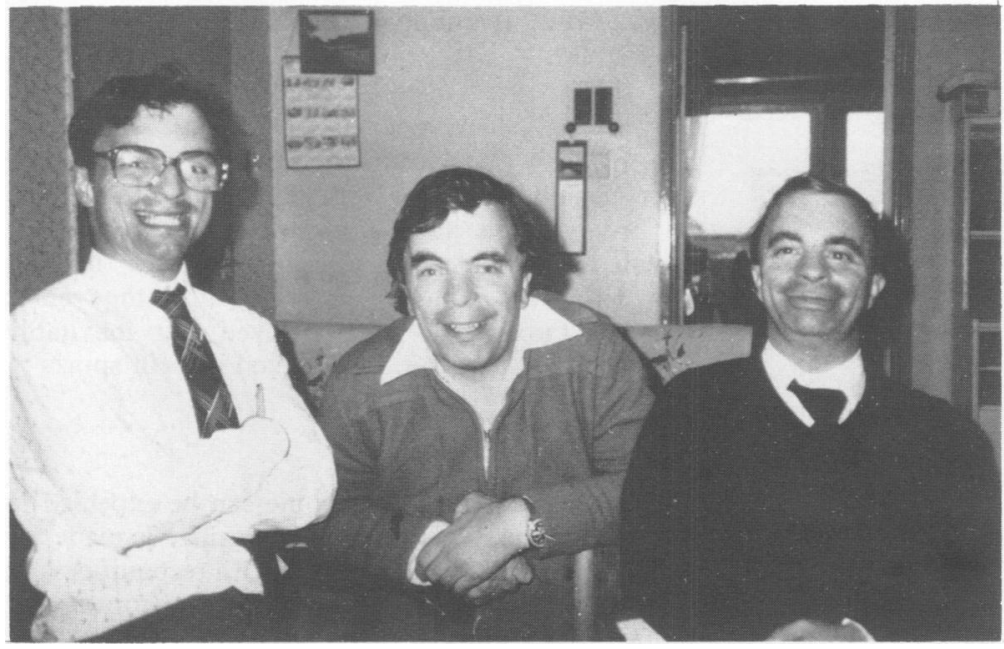

Figure 2 Three brothers with Aarskog syndrome. 

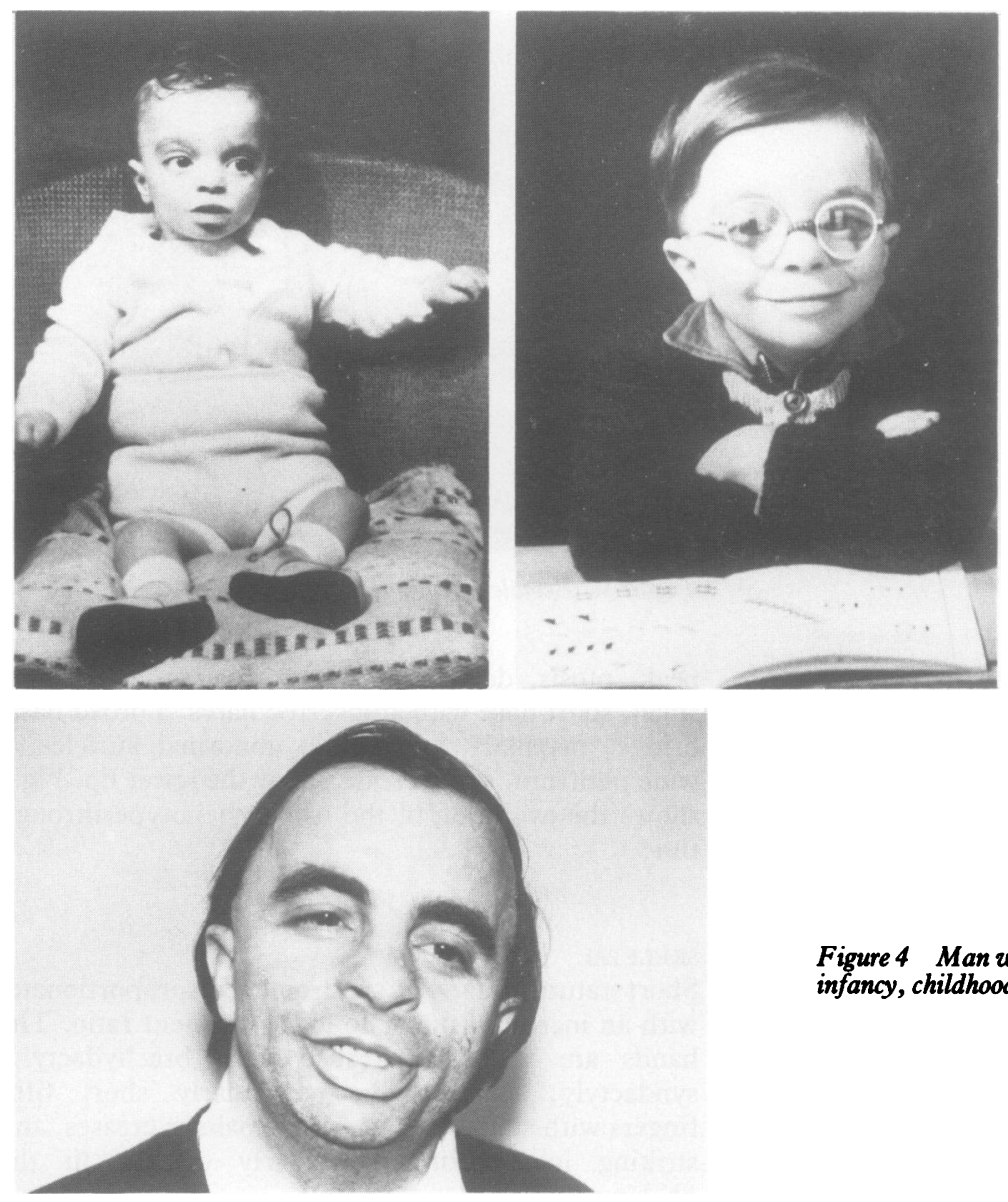

Figure 4 Man with Aarskog syndrome pictured in infancy, childhood, and as an adult.

ligamentous laxity, scoliosis, metatarsus adductus, and splayed toes with bulbous tips.

\section{GENITAL}

The characteristic abnormality in Aarskog syndrome is the shawl or overriding scrotum, though this need

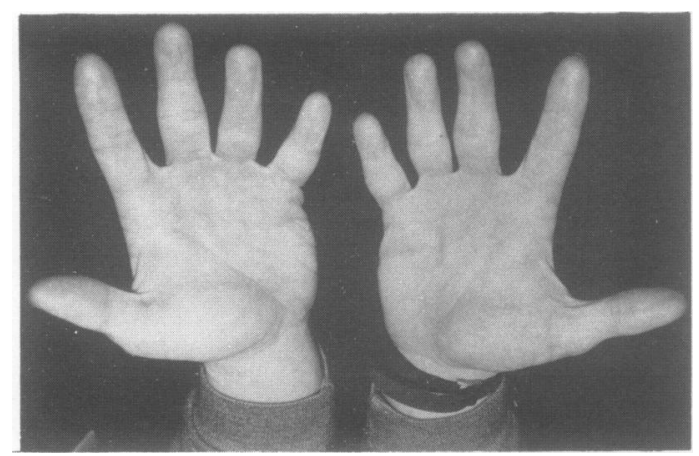

Figure 5 The hands in Aarskog syndrome. not be a constant feature. It becomes much less obvious with age. Cryptorchidism is common as are inguinal herniae. If the cryptorchidism is corrected early, fertility is unimpaired.

\section{GROWTH}

The majority of males with Aarskog syndrome are short, usually below the 10th centile and often below the 3rd. Infants have a normal birth weight but growth falls away across the centiles over the first year. Children remain very small until they enter puberty. Puberty is often delayed but inevitably occurs bringing with it a prolonged growth spurt.

\section{INTELLIGENCE}

Subjects with Aarskog syndrome can be expected to have normal intelligence when allowance is made for the ascertainment bias associated with recognition and reporting of handicap in dysmorphic syndromes, and the fact that a number of reported cases with mental 
handicap do not satisfy the diagnostic dysmorphic criteria. The proportion of mentally handicapped persons does not show a statistically significant excess over that in the general population, although the sample size is too small to exclude positively an association with mild learning difficulties.

\section{VISION}

There is an increased incidence of hypermetropia in persons carrying the gene for Aarskog syndrome.

\section{LIFE EXPECTANCY}

Aarskog syndrome is associated with a normal life span.

\section{Differential diagnosis}

The differential diagnosis of Aarskog syndrome includes Noonan syndrome and Robinow syndrome. Aarskog syndrome is not associated with heart defects or major genital abnormalities and caution should be exercised before making a diagnosis of Aarskog syndrome if they are present.

We would like to thank Dr John Burn for introducing us to the Newcastle family and for his comments on this manuscript. We also thank the families involved for all their help. M Porteous was in receipt of an MRC grant at the time that this work was carried out.
1 Aarskog D. A familial syndrome of short stature associated with facial dysplasia and genital anomalies. I Pediatr 1970;77: 856-61.

2 Scott CI. Unusual facies, joint hypermobility, genital anomaly and short stature: a new dysmorphic syndrome. Birth Defects $1971 ; \mathrm{VII}($ No 6):240-6.

3 Bawle E, Tyrkus M, Lipman S, Bozimowski D. Aarskog syndrome: full male and female expression associated with an X-autosome translocation. Am F Med Genet 1984;17:595-602.

4 Berman P, Desjardins C, Fraser FC. The inheritance of the Aarskog facial-digital-genital syndrome. $f$ Pediatr 1975;86: 885-91.

5 Berry C, Cree J, Mann T. Aarskog's syndrome. Arch Dis Child 1980;55:706-10.

6 Duncan PA, Klein RM, Wilmot PL, Shapiro LR. Additional features of the Aarskog syndrome. F Pediatr 1977;91:769-70.

7 Friedman JM. Umbilical dysmorphology, the importance of contemplating the belly button. Clin Genet 1985;28:343-7.

8 Funderburk Sj, Crandall BF. The Aarskog syndrome in three brothers. Clin Genet 1974;6:119-24.

9 Furukawa CT, Hall BD, Smith DW. The Aarskog syndrome. f Pediatr 1972;81:1117-22.

10 Fryns JP, Macken J, Igodt-Ameye L, van den Berghe $H$. The Aarskog syndrome. Hum Genet 1978;42:129-35.

11 Grier RE, Farrington FH, Kendig R, Mamunes P. Autosomal dominant inheritance of the Aarskog syndrome. Am $\mathcal{J}$ Med Genet 1983;15:39-46.

12 Hassinger DD, Mulvihill JJ, Chandler JB. Aarskog's syndrome with Hirschprung's disease, midgut malrotation, and dental anomalies. F Med Genet 1980;17:235-8.

13 Hoo JJ. The Aarskog (facio-digito-genital) syndrome. Clin Genet 1979;16:269-76.

14 Hurst DL. Metatarsus adductus in two brothers with Aarskog syndrome. F Med Genet 1983;20:477.

15 Maxwell GM. Aarskog's syndrome. Med F Aust 1982; 24 July.

16 Melnick M, Shields ED. Aarskog syndrome: new oral-facial findings. Clin Genet 1976;9:20-4.

17 Pedersen JC, Fryns JP, Bracke P, Geeraert M, van den Berghe H. The Aarskog syndrome. Ann Genet (Paris) 1980;23:108-10.

18 Sugarman GI, Rimoin DL, Lachman RS. The facial-digital genital (Aarskog syndrome). Am $\mathcal{F}$ Dis Child 1973;126:248-52.

19 van den Bergh P, Fryns JP, Wilms G, Piot R, Dralands G, van den Bergh R. Anomalous cerebral venous drainage in Aarskog syndrome. Clin Genet 1984;25:288-94.

20 van de Vooren MJ, Niermeijer MF, Hoogeboom JM. The Aarskog syndrome in a large family; suggestive for autosomal dominant inheritance. Clin Genet 1983;24:439-45. 